\title{
Decisive factors for the adoption of E-Procurement in manufacturing firms in India
}

\author{
Satyaodai Bhadaoria ${ }^{1}$, Kiran Karande ${ }^{2}$ \\ ${ }^{1,2}$ Symbiosis Institute of Operations Management,Symbiosis International (Deemed University), Pune, India
}

\begin{abstract}
E-Procurement is not only just a method for purchasing goods or ordering online but much more than that. Some firms adopt and excel in e-procurement, while others fail. This research was carried out among large scale manufacturers in India on the adoption of e-procurement. The research and study is based on three key objectives: to study the intensity, impact and challenges faced by the organizations in India in adopting E-procurement in their operations. A study of the major manufacturing firms working in India was included in the study. In attempting to decide the variables that impact the performance of e-procurement programmes, the analysis followed a descriptive approach. From a list of 233 major manufacturing firms, a sample size of 38 respondents was chosen. Data was obtained by floating a questionnaire from the respondents. The data obtained was thoroughly analyzed and displayed in the tables using SPSS. The study observed that most of the large scale manufacturers in India have welcomed eprocurement with various practices of e-procurement such as: online advertising of tenders, online short listing of vendors, online tenders submission among other items.
\end{abstract}

Article Received: 10 August 2020, Revised: 25 October 2020, Accepted: 18 November 2020

\section{Introduction}

In a robust supply chain, the procurement process being a non-costumer facing operating activity acts as one of the major driver of the extended supply chain. The sole aim of procurement is to deliver the right product at right time at the right place and at the most competitive price (Ali, 2018).

However, to achieve this, the focus of the management of the companies shifts to the purchasing process and the purchasing department are put up in extreme pressure. Not only the success of the purchasing department is considered as a positive impact on the business but also considered as one of the key factor in executing the strategic and tactical objectives (Slevin \& Pinto, 1987). Also it has resulted in heightened emphasis on the cost of the materials and the purchased services. Thus, to attain corporate success, the organizations are constantly involved in matching the technological competence and capabilities of the suppliers with an ultimate aim of reducing costs. There is a need to transform the role of the purchaser with the evolving technology.

E- Procurement adoption by the organizations has resulted in operational excellence. Various Research studies have proved that the impact of E-Procurement in the organizations has led to the change in the roles of procurement specialists and this is evident in the larger need for workforce growth and preparation in fields such as strategic procurement and product research to improve market analytics skills (Eadie et al., 2011). EProcurement is seen as the value-added process which streamlines the procurement process. EProcurement aims to computerize most of the work process, leverage spending power, reduce procurement lead time and focus on identification of new Internet-based procurement prospects. The technologies of E-Procurement include Eprocurement software, spend management, B2B market exchanges, Reverse auctions which have been credited with offering impressive advantages for businesses adventuring in them. Such benefits involve lowering operating expenses, shortening the order delivery lead period, decreasing inventory rates and the price paying for goods, and planning partnerships for expanded cooperative technical activity and coordinating with business associates.

Therefore, the study is aimed at accomplishing the following three objectives: to determine the degree to which e-procurement was embraced by large-scale producers in India have; to determine the crucial success factors which leads to the adoption of e-procurement in large Indian scale manufacturing companies.

\section{Literature Review}

According to (Mose et al., 2013) there are a range of industrial organizations that have not 
completely implemented frameworks for eprocurement. To determine the cause why some organizations have not included all the activities of procurement in e-procurement, it would be necessary to conduct a report.

The purchase of products and services without the use of paper processes is e-procurement(Gupta \& Narain, 2012). For the last few years, public and private sector companies have used information technology to streamline and simplify their buying and other procedures. E-Procurement platforms have only gained interest in the last decade. While there is a discussion regarding the recent advent of e-Procurement, there is no question that the quick adoption of internet in e-Procurement presents some advantages over previous inter organizational instruments (Vaidya et al., 2006).

To improve the efficiency and accountability in various government procurement steps, majority governments in developing and industrialised countries would like to have a public eprocurement channel (Henriksen \& Mahnke, 2005). The theory of government procurement is straightforward: to get the right product at the right price at the right time. It should be a costless, unbiased and straightforward process (Boardman et al., 2008). Fraud in public procurement systems raises concerns such as lack of responsibility and transparency, Lack of auditing and political scrutiny, pathetic bureaucratic professionalisation but communication technology plays an important role in reducing corruption by promoting fair and efficient governance (Lane \& Stagg, 2014).

For the future of today's dynamic and global society the setting, introduction and acceptance of the e-Procurement is a matter of extreme concern. Organizations appear to be obsessed by the adoption of new ones due to the tremendous

\begin{tabular}{|l|l|}
\hline Level of Adoption & Percentage of Respondents \\
\hline Already Adopted E-procurement & 44.7 \\
\hline Planning to adopt in coming 5 years & 42.1 \\
\hline No plan of adoption & 13.1 \\
\hline
\end{tabular}

Table 1: Level of adoption of E-procurement by various organization

The organizations which have adopted Eprocurement solutions are basically medium or large scale manufacturing companies. As increase in orders online tends to increase the number of benefits provided by e-Procurement technologies including e-Procurement.

(Khanapuri et al., 2011) say that there are a range of e-procurement framework adoption criteria. They include technologies, priorities, records, skills and staffing. Above mentioned conditions results in adoption process facing a range of difficulties, such as employee compatibility, incorporation, adoption and daily usage and lack of capability by small providers.

\section{Survey Aim and Background:}

The survey aims to determine the factors behind the adoption of E-procurement and the challenges faced in adoption. It begins with the check of the readiness of the adoption of E-procurement in the manufacturing industry, followed by an intensity check to identify the procurement activities carried online and then observing the impact of the e-procurement initiatives that comprises of certain benefits and challenges.

Once the critical factors are identified, the next step is the preparation of the questionnaire which will be used for the survey of manufacturing companies. The survey is divided into certain stages. The first stage is based on level of adoption of E- Procurement. A total of 41 respondents from 41 different organizations were surveyed. The survey was based on the level of adoption to know which organization have already adoption, which organization are planning to adopt and which organization does not intend to adopt. Out of this 38 filled up the questionnaire and responded to the present level of adoption and their future plans regarding the adoption of Eprocurement.

\footnotetext{
in orders online tends to increase the number of
}
employees the adoption of online procurement activities is evident.

\section{No plan to adopt E-procurement}

The organization who did not want to adopt EProcurement are the ones with less employee size 
or are the start ups who don't want to adopt due to high cost of implementation.

An extension in the survey questionnaire was provided for the organizations which adopted already E-procurement to determine the number

\begin{tabular}{|l|l|}
\hline Level of Implementation & Percent \\
\hline Experimented at first Level & $7 \%$ \\
\hline Completely implemented in one business unit & $24 \%$ \\
\hline $\begin{array}{l}\text { Completely implemented in greater than one } \\
\text { business unit }\end{array}$ & $22 \%$ \\
\hline Partially implemented in one department & $32 \%$ \\
\hline Fully implemented in all department & $15 \%$ \\
\hline
\end{tabular}

Table 2: Implementation level of E-procurement in already adopted E-procurement company

Table 2 helps us to understand that the Eprocurement adoption in Indian companies are at the beginning stage as $63 \%$ of the companies have E-procurement adopted in one or less department.

Intensity of Activities performed Online:

\begin{tabular}{|l|l|}
\hline E-Procurement Activities & \multicolumn{1}{|c|}{ Per cent (Company Activity) } \\
\hline Online Ordering & $52 \%$ \\
\hline Order Approvals & $45 \%$ \\
\hline Purchase Order & $43 \%$ \\
\hline Online Invoicing & $32 \%$ \\
\hline Payments & $31 \%$ \\
\hline
\end{tabular}

Table 3: Intensity of E-procurement activities performed online

Respondents also identified the products and services that were most commonly purchased online which included office supplies, hardware, software, MRO products and products related to logistics and distribution.

\section{Impact of the E-procurement activities:}

Respondents in the survey were expected to identify the benefits received from the adoption of the E-procurement services. No major benefits were reported by the respondents. The normal benefits that were observed are present in table 4 . This is because it may be very soon to expect a significant benefit from the implementation of $\mathrm{E}$ procurement activities from these organizations.

Improved sourcing of suppliers

Reduction in employee strength

Reduction in procurement lead time

\section{E-Procurement adoption levels}

$\mathbf{N}$

Online Tender 38

Advertisement of departments or divisions in which Eprocurement has been partially implemented or completely along with the level of implementation.
Respondents from their respective companies were asked to recognize the e-procurement activities which are used in their organization. From the survey, the top 5 activities which were performed online is mentioned which includes order placing, tracing, invoicing, payments. 
Submission of proposal 38

through online mode

Online Vendor 38

Selection

Online Requisition by 38

different departments

Proposals performed 38

through the Firm's

online portal

Presence of Online 38

portal

Item description display 38

on company's portal

In the above table, the large scale manufacturing firms with a mean $\geq 3.5$ were with a great extent performed online advertisement of tenders, allowed the vendor online submission, shortlisted supplier through online supplier, allowed different company departments to call for online requisition and proposals through online portal. This shows that large scale manufacturing companies in India have e-procurement adoption to a large extent. The data is aligned with the research of (Croom \& Brandon-Jones, 2005)who suggest that eprocurement platform enables the organization to execute any level procurement process such as finding and evaluating suppliers, requisition, request for quotation, negotiation, purchasing, delivery tracking, 3 Way matching and invoice generation.

On the other side, the presence of online portal/website for the manufacturing companies and displaying item description online within the large scale manufacturing firms in India have been adopted to a normal extent where mean $\geq 3.0$. This can be linked with the challenges such as use

\section{Critical}

Success N

Factors

Senior officials 38

commitment

to e-

procurement

Rules and regulations 38 compliance

Buyers trust on system 38

Processes aligned with 38

Automation

Selection of system 38

through competitive

bidding

Readiness of Employees 38

for E-procurement

3.76

1.898

3.69

3.67

2.98

of very old equipment, components and parts where the documentation process is paper based and lacks the necessary digital format as hinted by (Foroughi, 2015).

\section{Crucial Success Factors in E-Procurement Adoption}

Many different factors can ascertain the successful adoption of E-procurement in manufacturing companies. These are some of the most crucial factors that an organisation needs to consider in their work to implement the E-procurement systems focussed at improving their competitiveness advantage. The respondents indicated the level to which they will agree with different factors that will contribute to the easy adoption of e-procurement among large manufacturing organizations in India using a five likert scale of 1 - Very large extent, 2 - large extent, 3 - Normal extent, 4 - Small extent, 5 Very small extent. The results shown in table below.

Mean

2.11

2.18

2.28

\section{Standard Deviation}

.922

.709

.738

.749

1.199 
Performance

Improvement through

performance evaluation

Monitoring Procurement 38

regulations and

guidelines

Employees willingness 38

to adopt e-procurement

system

Use of e-procurement 38

operations manual

Transforming manual 38

procedures in alignment

with e-procurement

Efficient management of 38

risk

Regular measurement of 38

the performance of $\mathrm{E}$ -

procurement

Supplier Involvement in 38

E-procurement

operations

Updated procurement 38

Information

Competitive acquisition 38

of E-Procurement

system

Employee training on e- 38

procurement usage

Critical Info Availability 38

on portal

Suppliers training on e- 38

procurement functions

No seriousness shown 38

by senior management

towards E-procurement

From the above table, regular engagement by senior management (mean $\leq 2.99$, with a substantial standard deviation), provision of eprocurement practises, engaging vendors in eprocurement implementation, modifying manual operations in favour of e-procurement, developing new automation processes, competitively purchasing of e-procurement systems, competitive bidding, willingness of employees to adopt Eprocurement system, periodic e-procurement efficiency assessment, compliance with procurement guidance, rules and regulations compliance, device buyer confidence, up to date procurement data and effective risk management has indicated Large-scale manufacturing firms in
2.36

.678

.698

India have implemented workers preparation to make e-procurement effective. The results are in accordance with the findings that other scholars have made. For example (Kamotho \& Kamotho, 2014)found that the adoption process should be carried out, as far as possible, in accordance with all corporate practises, in order for each company to ensure the accomplishment of e-Procurement steps.

The results also shows that training of employees on the use of e-procurement, the availability of accurate website information and training of eprocurement suppliers have been reasonably successful in implementing e-procurement among 
large-scale manufacturing companies in India $(3 \geq$ mean $\leq 3.5$ ).

The findings also reveal that the CEO worries to a limited degree about the implementation of eprocurement $($ mean $=4.32)$. This can be because most of the people surveyed were CEOs and head of the departments who, although it adversely reflected on them, may not have agreed to the argument. The variables in the above table were much too many and factor analysis was then further carried out to minimise them to a reasonable amount.

Crucial success factor rotational component matrix has been used and the results are as follows:-

Critical Success Factors Rotated Component Matrix

\begin{tabular}{|c|c|c|c|c|c|c|}
\hline \multirow{3}{*}{\begin{tabular}{|l} 
Critical Success Factors in e-procurement \\
Efficient management of risk
\end{tabular}} & \multicolumn{5}{|c|}{ Component } & \multirow{3}{*}{$\begin{array}{l}\text { Factor } \\
\text { Name } \\
\text { Factor } 1: \\
\text { Employees }\end{array}$} \\
\hline & & & & & & \\
\hline & .912 & .191 & -.048 & .162 & .109 & \\
\hline $\begin{array}{l}\text { Transforming manual procedures in alignment } \\
\text { with e-procurement }\end{array}$ & .837 & -.214 & -.354 & .146 & -.047 & $\begin{array}{l}\text { Administrati } \\
\text { on }\end{array}$ \\
\hline Updated procurement Information & .819 & .523 & -.061 & .013 & -.094 & Contribution \\
\hline Senior officials commitment to e-procurement & .817 & -.079 & .133 & .489 & .155 & success \\
\hline Readiness of Employees for E-procurement & .811 & .138 & .029 & .293 & .086 & \\
\hline $\begin{array}{l}\text { Training of Employees on e-procurement } \\
\text { adoption }\end{array}$ & 756 & .124 & -.059 & .122 & .587 & \\
\hline $\begin{array}{l}\text { Regular measurement of the performance of E- } \\
\text { procurement }\end{array}$ & .625 & .521 & -.083 & 287 & -.144 & \\
\hline Critical Info Availability on portal & .205 & .954 & -.029 & -.056 & 423 & \\
\hline Suppliers training or & -.094 & .841 & -.132 & .118 & .410 & Technology \\
\hline $\begin{array}{l}\text { Competitive acquisition of E-Procurement } \\
\text { system }\end{array}$ & t. 065 & .830 & -.131 & .168 & .171 & $\begin{array}{l}\text { and Supplier } \\
\text { Performance }\end{array}$ \\
\hline \begin{tabular}{|lll}
$\begin{array}{l}\text { Supplier Involvement in } \\
\text { operations }\end{array}$ & E-procurement \\
\end{tabular} & 277 & .591 & -.047 & .469 & .235 & Efficiency \\
\hline Buyers trust on system & .495 & .498 & .361 & .110 & -.439 & \\
\hline $\begin{array}{l}\text { Performance Improvement through performance } \\
\text { evaluation }\end{array}$ & -.124 & -.080 & .928 & -.014 & .131 & $\begin{array}{l}\text { Factor 3: } \\
\text { Performance }\end{array}$ \\
\hline Rules and regulations compliance & .008 & -.082 & .849 & -.055 & .039 & monitoring \\
\hline Efficient management of risk & -.124 & -.345 & .522 & .118 & -.542 & $\begin{array}{l}\text { procurement } \\
\text { systems }\end{array}$ \\
\hline $\begin{array}{l}\text { Transforming manual procedures in alignment } \\
\text { with e-procurement }\end{array}$ & 188 & -.070 & .070 & .815 & .116 & $\begin{array}{l}\text { Factor 4: E- } \\
\text { Procurement }\end{array}$ \\
\hline Updated procurement Information & .375 & .410 & -.024 & .684 & .131 & Applications \\
\hline Senior officials commitment to e-procurement & .356 & 375 & -.253 & .659 & -.110 & Adoption \\
\hline Readiness of Employees for E-procurement & .291 & .130 & .166 & .132 & .877 & Factor \\
\hline $\begin{array}{l}\text { Training of Employees on e-procurement } \\
\text { adoption }\end{array}$ & $t-.304$ & .369 & .285 & .217 & .590 & $\begin{array}{l}\text { Assistance } \\
\text { from } \\
\text { Management }\end{array}$ \\
\hline
\end{tabular}

Factor 1: 
Employee and Transformational Leadership to Implementation Progress: The most important success factor is employee and management readiness and commitment towards the success of e-procurement adoption by manufacturing companies in India. In order for the eProcurement portals to be competitive, workers should be able to concentrate on their day to day work without losing the visibility that management should control corporate spending efficiently. That can be done by the preparation of personnel and the communication of both the requirements and procurement that can make the technologies easier to use. The vision and the priorities that are important to the organization's goals should be set by management. Policies and policies that will enable the implementation of technology should be formulated and defined. Management should also provide all the financial resources required for the growth of the eprocurement infrastructure in order to promote its acceptance.

\section{Factor 2:}

Information Technology Reliability and Supplier Performance: Information technology reliability is very critical in e-procurement adoption. Reliable electronic systems boost information reliability, minimising risks, leading to higher levels of adoption from vendors and consumers. Large manufacturing companies in India must make sure that the online portal content is complete, appropriate and easy to understand and safe, in order to achieve reliability. This would encourage vendors with reduced risks to perform their transactions. Supplier efficiency is also crucial to the growth of e-procurement adoption within India's large manufacturing companies. Therefore, this means that vendors should be interested starting from the beginning stages of the implementation of e-procurement. The supplier's training on the application of the technology would also increase efficiency on e-procurement adoption. If the management needs to make some adjustments to the scheme, the vendors should still be involved in negotiations. This will contribute to the successful introduction of etechnology in large Indian manufacturing companies.

\section{Factor 3:}

Monitoring the efficiency of e-procurement systems: In the course of implementing an appropriate procurement solution, each sector has its own specific transformational challenges. It is vital to embrace performance management in adoption of e-procurement by large manufacturers in India, as this will confirm that the adoption process is aligned with organisational rules and regulations, therefore contributing to eprocurement progress. In order to realise optimum advantages, success management would also make sure that the e-procurement process is fully applied. Continuously measuring the main benefits of e-procurement is essential for largescale manufacturing companies in India, as it is crucial for the successful implementation of the method. This includes the development of objectives and goals for success. This defined priorities would help the organisation to assess how much has actually been done with respect to the implementation of the e-procurement system.

\section{Factor 4:}

E-Procurement Systems Customer Approval: The acceptance of e-procurement systems by consumers was another significant aspect that was found to be crucial to the progress of eprocurement adoption. The adoption of eprocurement systems by customers would contribute to the growth of the system as those involved will have a constructive outlook about learning how to use the system, making it easier to implement more of the operations into the system.. The easy use of the e-procurement system by the customers requires understanding the value of the ease of using the e-procurement system for its employees by senior management and then selecting an easy to navigate programme. Auto routing of purchase order to acceptable clearance supervisors, access to e-catalogues, giving suppliers purchase orders, generating capabilities for cost monitoring, allows staff get use to the system without any delay. This will lead to effective adoption by large-scale manufacturers in India of e-procurement systems.

\section{Factor 5:}

Support from top management has also been recognized as a crucial factor contributing to the progress of the implementation of e-procurement from the solved part matrix. If an enterprise 
wishes to effectively embrace e-procurement, so senior management must endorse the application of the technology in their corporation and incorporate it into its ultimate objective. It is the responsibility of the executive committee to set the vision and priorities, taking Collective participation to improve procedures and operational frameworks and to devise the policies and plans required for the introduction of an eprocurement initiative. If India encourages the implementation of e-procurement at the senior most levels among the large scale firms in India, the businesses will effectively implement eprocurement systems. In the other hand, there is any excuse for the method to malfunction if the eprocurement processes have very limited support from the top level teams. Therefore, the management of large-scale manufacturing companies in India should set priorities, plans and baselines that are appropriate for e-technology adoption. The tactics should be in accordance with the priorities of the companies. The benchmarks would enable companies to assess how much they will accomplish in terms of the implementation process of the e-procurement system.

\section{Conclusion}

The study showed that the bulk of India's largescale production companies had embraced eprocurement. It is obvious, however, that online advertisement tenders, encouraging suppliers to request online proposals, brief online catalogue of suppliers, enabling company workers to make online requisitions and call for various proposals via the company website presence as eprocurement activities that has been adopted among most of the large scale manufacturers in India. The study identified the following five key factors from the factor analysis that contribute to e-procurement success among large-scale Indian manufacturers and management dedication to implementation success; information technology efficiency and supplier results; e-procurement systems performance monitoring; e-procurement systems user acceptance and top management support from the factor analysis. It can be inferred from the results of the report that, to a greater degree, the most of the of large-scale manufacturers in India have embraced eprocurement which is being followed by eprocurement practices: online advertising of tenders, tender submission in online mode and online short listing of vendors among other items. The five key factors found from the research that contribute to the growth of e-procurement among large manufacturers in India are: employee and management contribution to implementation success; IT Systems and supplier performance reliability; e-procurement systems performance monitoring; e-procurement systems top level management support and user acceptance.

\section{Reference}

[1] Ali, M. (2018). An integrated framework for improving supply chain performance An Integrated Framework for Improving Supply Chain Performance.

[2] Boardman, A. E., Siemiatycki, M., \& Vining, A. R. (2008). Public-Private Partnerships in Canada and Elsewhere $\dagger$. Canadian Public Administration, 51(1), 944.

[3] Croom, S. R., \& Brandon-Jones, A. (2005). Key issues in e-procurement: Procurement implementation and operation in the public sector. Journal of Public Procurement, 5(3), 367-387. https://doi.org/10.1108/jopp-0503-2005-b004

[4] Eadie, R., Perera, S., \& Heaney, G. (2011). Analysis of the use of e-procuremnt in the public and private sectors of the UK construction industry. Electronic Journal of Information Technology in Construction, 16(January), 669-686.

[5] Foroughi, A. (2015). MRO and eProcurement: Opportunities and Challenges. Statewide Agricultural Land Use Baseline 2015, 1(January 2008), 1-9.

[6] Gupta, M., \& Narain, R. (2012). A survey on adoption of e-procurement in Indian organisations. International Journal of Indian Culture and Business Management, $5(1)$, 76. https://doi.org/10.1504/ijicbm.2012.044019

[7] Henriksen, H. Z., \& Mahnke, V. (2005). EProcurement Adoption in the Danish Public Sector. Scandinavian Journal of Information Systems, 17(2), 85-106. 
[8] Kamotho, K., \& Kamotho, D. K. (2014). EProcurement and Procurement Performance among State Corporations in Kenya. International Journal of Science and Research, 8(2), 53.

[9] Khanapuri, V. B., Nayak, S., Soni, P., Sharma, S., \& Soni, M. (2011). Framework to Overcome Challenges of Implementation of E-procurement. Business Management, 2001, 208-215.

[10] Lane, M., \& Stagg, A. (2014). Australasian Journal of Information Systems Volume 18 Number1 2013. Australasian Journal of Information Systems, 18(3), 53-74.

[11] Mose, J. M., Njihia, J. M., \& Magutu, P. O. (2013). E-Procurement Adoption Among Large Scale Manufacturing Firms in Nairobi , Kenya. European Scientific Journal, 9(13), 375-401.

[12] Slevin, D. P., \& Pinto, J. K. (1987). Balancing Strategy and Tactics in Project Implementation. Sloan Management Review, 29(1), 33-41.

[13] Vaidya, K., Sajeev, A. S. M., \& Callender, G. (2006). Critical factors that influence eprocurement implementation success in the public sector. Journal of Public Procurement, 6(1/2), 70-99. https://doi.org/10.1108/jopp-06-01-02-2006b004 